\title{
The Impact of Horizontal Mergers on the Performance of the Jordanian Banking Sector
}

\author{
Yusuf Ali AL-HROOT ${ }^{1}$, Laith Akram AL-QUDAH ${ }^{2}$, Faris Irsheid ALKHARABSHA ${ }^{3}$ \\ Received: May 11, 2020 Revised: May 17, 2020 Accepted: June 09, 2020
}

\begin{abstract}
This paper examines the impact of mergers on the financial performance of the Jordanian banking sector. This paper applies the financial approaches in analysing the effects of mergers on Jordanian banks' performance for two the periods: four years pre-merger and four years' post-merger for the period from 2001 to 2009. The sample of the study solely contains the case of the merger of the Jordan Ahli Bank (AHLI bank) with Philadelphia Bank in 2005. Data are tested for normality using the Shapiro-Wilk Test and Kolmogorov Smirnov test. The financial ratios and a statistical technique as a Mann-Whitney U test were used to assess the significant differences in the financial performance of the selected banks pre- and post-merger by investigating the performance-related financial ratio groups that are expressed by leverage, liquidity, efficiency, and cash flow ratio. The results show that there is an insignificant improvement in the ratios of AHLI bank in the period after the merger, except for the superior result provided by this study indicating that the leverage ratios improved significantly. The reason for the insignificant improvement in financial ratios may be that the post-merger period corresponds to the period of the global financial crisis that began in 2007.
\end{abstract}

Keywords : Horizontal Mergers, Financial Performance, Banking Sector, Operational Performance Approach, Jordan.

JEL Classification Code: G34, M49, G21.

\section{Introduction}

The World Bank classifies the countries' economies into four income categories: high, upper-middle, lower-middle, and low. Jordan's economy is classified as an upper-middle income country. The banking sector is Jordan's largest economic sector, representing 15 percent of the nation's total GDP. The meaning of the merger and procedures going through mergers are provided in Part 11 of the Jordanian

${ }^{1}$ First Author and Corresponding Author. Assistant Professor, Department of Accounting, Faculty of Business, Philadelphia University, Jordan [Postal Address: P.O. Box 1, Amman, Jordan 19392] Email: yhroot@philadelphia.edu.jo

${ }^{2}$ Associate Professor, Al-Balqa Applied University (Amman University College for Financial \& Administrative Sciences), Amman, Jordan. Email: al_qudah2006@yahoo.com

${ }^{3}$ Assistant Professor, Al-Balqa Applied University, Salt, Jordan. Email: fariskhkh@yahoo.com

() Copyright: The Author(s)

This is an Open Access article distributed under the terms of the Creative Commons Attribution Non-Commercial License (http://Creativecommons.org/licenses/by-nc/4.0/) which permits unrestricted noncommercial use, distribution, and reproduction in any medium, provided the original work is properly cited. companies' law no. 22 of 1997 and its amendments from article (222) to article (239).

A merger is the combining of one or more corporations, limited liability companies (LLC), or other business entities into a single larger company to realise productivity and a high level of efficiency. As a brief history of the corporation mergers and acquisitions around the world, many examples may be mentioned: a start-up in 1779, the North West Company was a fur trading company headquartered in Canada; it was forced to merge with Hudson's Bay Company in 1821. The largest merger and acquisition combining the transaction value between companies is the merger of Mannesmann by Vodafone Air touch PLC, valued at US\$202 billion. The most common classification types of mergers were published by The Federal Trade Commission (FTC):

1. Horizontal mergers, which include one or more competitors.

2. Vertical mergers, which include one or more buyer-seller relationships.

3. Potential competition mergers, in which the purchaser is likely to enter the market and turn into a potential competitor of the vendor or seller, or vice versa.

The main aims of a merger are to increase capabilities and revenue, gain a competitive advantage or larger market 
share, diversify products or services, cut costs and survive (this approach was used during the global crisis from 2008 to 2012).

In line with the results of previous studies, research shows that the financial performance has improved in the long-term post-merger. In addition, the stock price of merger companies increased post the merger deal. But the financial health of the merger firm illustrates an identical or better situation. In other studies it was found that the merger has a significant lowering of the financial permanence and is unsuccessful to create abundance for their shareholders. The main objectives of this study are: (a) to view the impact of mergers on the operating performance of the selected bank. (b) To compare and analyze the pre- and post-merger cash flow ratios, liquidity ratios, profitability ratios, and leverage ratios of the selected bank in the present study.

The remainder of this study is organized as follows: the 'History of Mergers in Jordan' section explains the history of the Central Bank of Jordan (CBJ) and AHLI bank. The 'relevant literature' section discusses relevant literature and forms the study hypotheses. In the 'Methodology' section, we describe the research methods and theoretical framework are provided. The 'Results' section presents and discusses the results of the study and the 'Conclusion' section contains the concluding remarks. Lastly, the article points to limitations and suggests future research.

\section{History of Mergers in Jordan}

In the late 20the century in 1959, the central bank was established in Amman city (capital of Jordan) on the recommendations of the Jordanian government. And is a government-owned. In addition, the Jordanian government has illustrated a revision to Banking Law No. 28 out of 2000 , giving the CBJ greater position and authority over the administration of banks (Al-Hroot, 2016).

The Jordan banking sector consists of 25 licensed banks. The number of local listed banks on the Amman Stock Exchange (ASE) totals 15 establishments. In addition, there are nine foreign bank subsidiaries and they are not listed on the ASE. Annex A shows the details of the banking sector in Jordan. In addition, Annex B shows the number of mergers in Jordan, with two mergers being recorded, namely, the merger of Philadelphia Bank with the Jordan National Bank (AHLI) in 2005, and the merger of the Jordan Gulf Bank and Mashreq Bank in 1993. Jordan Ahli Bank has a strong history, organized in the early of 1956 in Amman, Jordan Ahli Bank's capital reached 65 million later finishing all the legal policies of the merger; with a different code of (AHLI), and after March 2005, the Amman Stock Exchange (ASE) delisted Philadelphia Investment Bank (Al-Hroot, 2016).

\section{Literature Review}

There are essentially two methods used to assess the success of mergers and acquisitions. The first approach explains the impact of merger decisions on the stock price of the listed banking corporations. The second approach is the operational performance approach, which includes two methods, one of them being through accounting data (financial ratios) and the other being through the estimation of the cost and profit purposes.

\subsection{Operational Performance Approach}

In their study, Gupta and Banerjee (2017) examined the impact of mergers and acquisitions on the financial performance in India. The study empirically tests the sensitivities by using seven different merger and acquisitions firms across India from 2006 to 2012. In order to test the significance of the study, a t- test is used on financial ratios by SPSS for the purpose of data analysis and processing. The study concludes that in the post-merger period there is no improvement in financial performance. In addition, both liquidity and profitability indicators declined for the selected sample. Al-Hroot (2016) conducted a case study on the effect of the merger on the financial performance of Jordanian industrial companies; the sample included seven firms selected for the period between 2000 and 2014. Financial ratios and a statistical technique as a paired t-test were used to assess the significance of the before-after financial performance of the selected firms. The study results show an insignificant improvement in market share, profitability, and liquidity in the Jordanian industrial companies after the merger.

Moctar and Chen (2015) investigated the effect of mergers and acquisitions on the financial performance of the banking sector in West Africa. The study sample size contains two groups of banks. Secondary data were collected from the financial statement of the selected sample. To analyze the data, financial ratios such as the ROI, investment valuations ratios, ROE and liquid ratio indicate a negative effect of the mergers and acquisitions on the financial performance. Moreover, the study revealed that financial improvement could be achieved in the long-term.

Healy et al. (2011) found that there is a strong relation with a positive sign between the after-merger and increases in operating cash flows, and abnormal stock returns at merger announcements. Abbas and Hunjra (2014) investigated the effect of mergers and acquisitions on the financial performance of Pakistani banks. The study sample size contains 10 selected banks going through mergers and acquisitions. To achieve the objectives of the study, accounting ratios were calculated and analyzed for the period between 2006 and 2011. The paired t-test using SPSS is used to analyze the data. The results of the study show that there is no difference in financial 
performance between the periods before and after the merger, and the difference is insignificant. Ghosh and Jain (2000) investigated whether the mergers of corporations increase financial leverage. They find that a corporation's financial leverage merger could increase because of an increase in debt capacity or from an unused debt capacity from before the merger years. And they find it increases significantly that financial leverage of combined firms following the mergers. Gjirja (2003) assessed the impact of the mergers in Swedish banks' efficiency. The sample of this study contains 28 banks undergoing the merger for the period between 1984 and 2002. The statistical technique used in this study to analyze and test the significance involves un-balanced panel data. Furthermore, the results show that after the merger there are no improvements in the technical efficiency of the bank or they are insignificant.

\subsection{Other Approaches}

Joash and Njangiru (2015) examined the impact of mergers and acquisitions on the Financial Performance of Commercial Banks in Kenya in this study. The sample size of the study contained 14 banks merged or acquired for the period from 2000 to 2014 . The primary data of the study were collected via open and closed-ended questionnaires. Statistical tools such as a coefficient of correlation were used in the study. The results show that the shareholders' value increased by acquiring firms after the merger. Sufian and Abdul Majid (2007) focused on the banking sector in Singapore and the purpose of this study is to evaluate the impact of mergers on the performance of the banking sector. The sample of this study contains banks that underwent mergers and acquisition for the period from 1998 to 2004 in Singapore's banking sector. The statistical technique used to test the significance in this study is the Tobit regression (TR) and Data Envelop Analysis (DEA). The results show that the performance of banks has a significant negative impact due to low credit quality, and the efficiency of banks has a significant positive impact by profitability.

Said, Nor, Low, and Rahman (2008) demonstrated that the productive efficiency of merged banks has no significant improvement. But there are studies such as Ahmed and Ahmed (2014), Vitale and Laux (2012), Liargovas and Repousis (2011), and Kemal (2011) that investigate the impact of financial ratios, such as costs and efficiency measures and profitability, based on the financial statements data for the merged firms pre- and post-merger. The results showed that the overall financial performance of merged firms improved, but insignificantly in the post-merger period. The profitability, capital position and liquidity improved insignificantly, while the efficiency declined in the post-merger period.

Harwood, Nakola and Nyaana (2016) investigated the effects of the restructuring of the National Bank of
Kenya on the financial performance. The researchers used a questionnaire and published financial statements to achieve the objective of the study. It illustrates that there is a positive effect on the financial performance as a result of organizational restructuring and that this is not significant.

We can conclude from the relevant literature that the performance of the banks has impacted post-mergers and acquisitions. In addition, some studies showed that there is no improvement either significant or insignificant in the financial performance of banks in the post-merger period. To our knowledge this is the first study in Jordan which measures the impact of mergers on the Jordanian banking sector performance in the pre- and post-merger period; we will evaluate the before and after merger periods for the merged banks using ratios. The ratios used in this study are the cash flow ratio, liquidity ratios, profitability ratios, and leverage ratios. Based on the above review of the literature the following four hypotheses are developed:

H0: $\mu 1=\mu 2$ (there is no statistically significant difference between the profitability ratio of the pre- and post-merger of AHLI bank).

H0: $\quad \mu 1=\mu 2$ (there is no statistically significant difference between the liquidity ratio of the pre- and postmerger of AHLI bank).

H0: $\mu 1=\mu 2$ (there is no statistically significant difference between the leverage ratio of the pre- and postmerger of AHLI bank).

H0 $: \quad \mu 1=\mu 2$ (there is no statistically significant difference between the cash flow ratio of the pre- and postmerger of AHLI bank).

Where $\mu 1$ is the performance of the company pre-merger in the ratio of profitability, liquidity, leverage, and cash flow. And $\mu 2$ is the performance of the company post-merger in the ratio of profitability, liquidity, leverage, and cash flow.

\section{Research Methods and Materials}

\subsection{Data Collection Methods}

The primary data consist in financial ratios collected from the financial statements of selected banks to analyze and investigate the effect of mergers in terms of performance in the Jordanian banking sector. The secondary sources are collected from published papers that are related to the subject of this study.

\subsection{Theoretical Framework}

The theoretical framework is developed in Figure 1 for the purpose of this study. It shows the relationship between the merger as the independent variable and the performance 


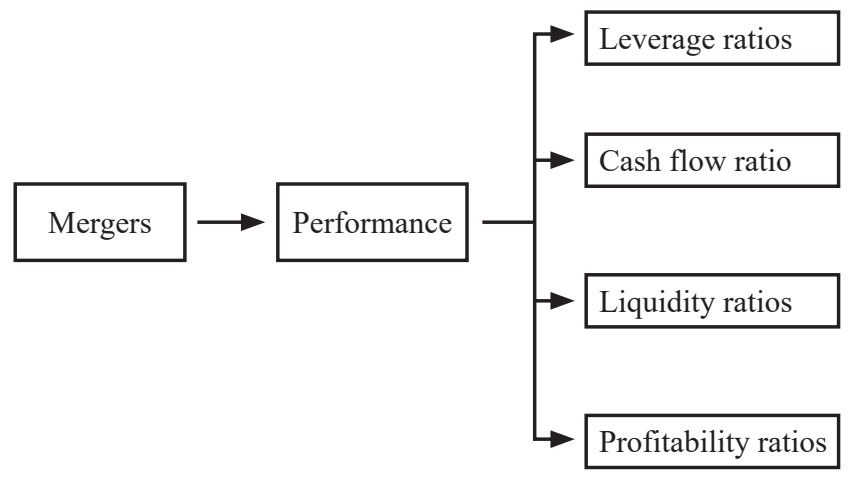

Figure 1: Theoretical framework

Table 1: List of ratios used to measure the performances of the merger banks

\begin{tabular}{|l|l|}
\hline Accounting ratios & \multicolumn{1}{|c|}{ Codes } \\
\hline Profitability ratios & $\begin{array}{l}\text { Interest spread(IS) } \\
\text { Return on Assets( ROA) } \\
\text { Interest margin(IM) } \\
\text { Return on Equity(ROE) }\end{array}$ \\
\hline Liquidity ratios & $\begin{array}{l}\text { Investment to Total Assets(ITA) } \\
\text { Investment ratio(IR) } \\
\text { Cash and Cash Equivalent to Total } \\
\text { Assets (CCETA) } \\
\text { Debt Ratio(DR) } \\
\text { Deposits to Total Assets(DTA) }\end{array}$ \\
\hline \multirow{2}{*}{ Leverage ratios } & $\begin{array}{l}\text { Total Deposits to Total Equity } \\
\text { (TDTE) } \\
\text { Equity Ratio (ER) }\end{array}$ \\
\hline \multirow{3}{*}{ Cash flow ratio } & $\begin{array}{l}\text { Cash generated from net cash flow } \\
\text { from operating activities to Profit } \\
\text { after tax(CCFPAT) }\end{array}$ \\
\hline
\end{tabular}

(financial ratios) as the dependent variable. The dependent variables are measured by using the leverage ratios, liquidity ratios, cash flow ratio, and profitability ratios; these financial ratios are used in many studies such as Kumar (2009); Kumbirai and Webb (2010); Kemal (2011); Ismail, Abdou and Annis (2011); Shah and Khan (2017). Table 1 exhibits the list of ratios used to measure the performances of the merger banks.

\subsection{Sample Size}

The sample of the study only contains the case of the merger of the AHLI bank with the Philadelphia Bank in 2005, resulting in the Jordan Ahli Bank. In addition, we could not study the other case (the merger of the Jordan Gulf Bank and Mashreq Bank in 1993, resulting in the Jordan Gulf Bank) because the Jordan Gulf Bank was undergoing another merger with the Arab bank and the financial statements are not available for the two merger situations.

\section{Results and Discussion}

\subsection{Shapiro-Wilk Test of Normality and Kolmogorov Smirnov Test}

To explore if the data are distributed normally or not, they should be tested for normality using the Shapiro-Wilk Test and Kolmogorov Smirnov test with the following hypotheses:

H0: financial ratios are normally distributed

$\mathrm{H} 1$ : financial ratios are not normally distributed

Table 2 shows the results from the Shapiro-Wilk Test and Kolmogorov Smirnov test of normality. The Shapiro-Wilk Test is more favourable for small sample sizes ( $<50$ samples). The interpretation of the Shapiro-Wilk Test is that if the Sig. value of the Shapiro-Wilk Test is greater than 0.05 (p-value $>$ 0.05 ), the data are normal. If it is below 0.05 (p-value $\leq 0.05$ ), the data significantly deviate from a normal distribution.

We can see from Table 2 that the p-value for all financial ratios is below 0.05 , the data significantly do not follow a normal distribution. Based on the results of the normality test, to test the differences in the financial performance pre- and post-merger for AHLI bank, we cannot use the test statistic ' $t$ ' (parametric statistics); to test the difference we have to use the Mann-Whitney U test (Nonparametric Test).

\subsection{Comparison of Financial Ratios of the AHLI bank Pre and Post-Merger}

Tables 3 illustrates the pre-merger situation data of several financial ratios of AHLI bank during the pre-4-year merger situation, the financial ratios, return on equity (ROE), return on assets (ROA), investment to total assets (ITA), interest margin (IM), net credit facilities to total deposits (NCFD) and equity ratio (ER) recorded a rising trend during the 4-year pre-merger period.

In the period after the merger situation, it was mentioned that the Interest Spread (IS) and Cash and Cash Equivalent to total assets (CCETA) showed a declining trend. While the ratios of deposits to total assets (DTA), debt ratio (DR), cash generated from net cash flow operating activities (CNOA) showed several trends.

\subsection{Descriptive Statistics}

Table 4 summarizes the descriptive statistics for each financial ratio group (mean, Std. Deviation, Minimum, and Maximum). Furthermore, this table does not provide us with vital information. 
Table 2: Normality Data Test for Financial Ratios

\begin{tabular}{|c|c|c|c|c|c|c|}
\hline \multirow{2}{*}{ Financial Ratios } & \multicolumn{3}{|c|}{ Kolmogorov-Smirnova } & \multicolumn{3}{|c|}{ Shapiro-Wilk } \\
\hline & Statistic & df & Sig. & Statistic & df & Sig. \\
\hline ROA & 0.329 & 8 & 0.010 & 0.195 & 8 & 0.006 \\
\hline ROE & 0.285 & 8 & 0.049 & 0.135 & 8 & 0.025 \\
\hline IS & 0.360 & 8 & 0.000 & 0.035 & 8 & 0.002 \\
\hline IM & 0.242 & 8 & 0.001 & 0.152 & 8 & 0.029 \\
\hline CCETA & 0.241 & 8 & 0.010 & 0.153 & 8 & 0.031 \\
\hline ITA & 0.283 & 8 & 0.006 & 0.076 & 8 & 0.023 \\
\hline DTA & 0.214 & 8 & 0.000 & 0.163 & 8 & 0.008 \\
\hline DR & 0.255 & 8 & 0.002 & 0.161 & 8 & 0.031 \\
\hline IR & 0.210 & 8 & 0.011 & 0.182 & 8 & 0.011 \\
\hline ER & 0.196 & 8 & 0.009 & 0.225 & 8 & 0.000 \\
\hline TDTE & 0.143 & 8 & 0.014 & 0.319 & 8 & 0.000 \\
\hline CCFPAT & 0.160 & 8 & 0.012 & 0.288 & 8 & 0.022 \\
\hline
\end{tabular}

Table 3: Comparison of Financial Ratios of the AHLI bank Pre and Post-Merger

\begin{tabular}{|c|c|c|c|c|c|c|c|c|}
\hline \multirow{2}{*}{$\begin{array}{l}\text { Financial } \\
\text { Ratios }\end{array}$} & \multicolumn{4}{|c|}{ After merger 4 years } & \multicolumn{4}{|c|}{ Before merger 4 years } \\
\hline & $\begin{array}{l}2009 \\
M+4\end{array}$ & $\begin{array}{l}2008 \\
M+3\end{array}$ & $\begin{array}{l}2007 \\
M+2\end{array}$ & $\begin{array}{l}2006 \\
M+1\end{array}$ & $\begin{array}{c}2004 \\
M-1\end{array}$ & $\begin{array}{l}2003 \\
M-2\end{array}$ & $\begin{array}{l}2002 \\
M-3\end{array}$ & $\begin{array}{c}2001 \\
M-4\end{array}$ \\
\hline \multicolumn{9}{|c|}{ Efficiency ratios / Profitability ratios } \\
\hline ROA & 0.008 & 0.008 & 0.006 & 0.012 & 0.004 & 0.000 & -0.003 & 0.000 \\
\hline ROE & 0.087 & 0.086 & 0.055 & 0.096 & 0.061 & 0.000 & -0.059 & 0.002 \\
\hline IS & 0.499 & 0.500 & 0.472 & 0.527 & 0.551 & 0.474 & 0.373 & 0.377 \\
\hline IM & 0.026 & 0.028 & 0.029 & 0.024 & 0.019 & 0.020 & 0.017 & 0.023 \\
\hline \multicolumn{9}{|c|}{ Liquidity ratios } \\
\hline CCETA & 0.310 & 0.343 & 0.422 & 0.430 & 0.553 & 0.485 & 0.483 & 0.414 \\
\hline ITA & 0.001 & 0.004 & 0.013 & 0.020 & 0.009 & 0.013 & 0.037 & 0.049 \\
\hline DTA & 0.673 & 0.652 & 0.629 & 0.626 & 0.831 & 0.811 & 0.749 & 0.740 \\
\hline DR & 0.904 & 0.904 & 0.900 & 0.878 & 0.938 & 0.944 & 0.954 & 0.949 \\
\hline IR & 0.543 & 0.542 & 0.482 & 0.468 & 0.322 & 0.406 & 0.443 & 0.539 \\
\hline \multicolumn{9}{|c|}{ Capital ratios / Leverage ratios } \\
\hline ER & 0.095 & 0.096 & 0.099 & 0.122 & 0.062 & 0.056 & 0.046 & 0.051 \\
\hline TDTE & 8.080 & 6.823 & 5.351 & 5.150 & 14.01 & 12.89 & 12.76 & 11.34 \\
\hline \multicolumn{9}{|c|}{ Cash flow ratio } \\
\hline CCFPAT & 3.920 & 2.020 & 10.22 & -10.63 & 43.62 & -16.56 & -15.61 & 6.201 \\
\hline
\end{tabular}


Table 4: Descriptive Statistics

\begin{tabular}{|l|c|c|c|c|c|c|}
\hline Types of Financial Ratios & Ratio & N & Mean & Std. Deviation & Minimum & Maximum \\
\hline \multirow{4}{*}{ Profitability ratios } & ROA & 8 & 0.004 & 0.005 & -0.003 & 0.012 \\
\cline { 2 - 7 } & ROE & 8 & 0.041 & 0.055 & -0.059 & 0.096 \\
\cline { 2 - 7 } & IS & 8 & 0.472 & 0.065 & 0.373 & 0.551 \\
\cline { 2 - 7 } & IM & 8 & 0.023 & 0.004 & 0.017 & 0.029 \\
\hline \multirow{5}{*}{ Liquidity ratios } & CCETA & 8 & 0.430 & 0.079 & 0.31 & 0.553 \\
\cline { 2 - 7 } & ITA & 8 & 0.018 & 0.017 & 0.001 & 0.049 \\
\cline { 2 - 7 } & DTA & 8 & 0.714 & 0.081 & 0.626 & 0.831 \\
\cline { 2 - 7 } & DR & 8 & 0.921 & 0.028 & 0.878 & 0.954 \\
\cline { 2 - 7 } & NCFTD & 8 & 0.468 & 0.078 & 0.322 & 0.543 \\
\hline \multirow{2}{*}{ Leverage ratios } & ER & 8 & 0.078 & 0.028 & 0.046 & 0.122 \\
\hline Cash flow ratio & TDTE & 8 & 9.676 & 3.624 & 5.15 & 13.84 \\
\hline
\end{tabular}

To compare two populations, the relevant statistical technique used to test the difference was the Mann-Whitney $\mathrm{U}$ test (Nonparametric Test). Furthermore, to test the significant difference in the financial ratios pre- and postmerger we applied the Mann-Whitney U test, when samples are independent such as pre- and post-merger. The analysis of the Mann-Whitney $U$ test is provided in two steps: the first one is the ranks table, displayed in Table 7, to show the differences, while the other table is the test statistics, displayed in Table 8, to show the significant differences.

\subsection{Differences between Groups}

Table 5 provides information regarding the output of the actual Mann-Whitney U test. It shows the differences between the groups mean rank and sum of ranks for the four groups of financial ratios tested (pre- and post-merger); if the ratio of the post-merger group is higher than the pre-merger group in mean rank then we indicate that there is an improvement (differences between groups) in the ratio post-merger. But if the ratio of the pre-merger group is higher than the postmerger group in mean rank then we indicate that there are declines (differences between groups) in the ratio postmerger.

Our first two groups of ratios ("Profitability and Cash flow ratio") indicate the largest difference in mean ranks between the pre and post-merger: the post-merger ratios exhibit significant improvements. A reversed pattern is observed for the other two groups ("Liquidity and Leverage ratios") except (NCFD) and the Equity Ratio increased.

\subsection{Significant Differences and Hypothesis Testing}

Based on our results from the analysis summarized in Table 6, the profitability ratios, ROA, ROE, and IM ratios increased significantly, while the IS ratio decreased insignificantly. We thus accepted hypothesis $\mathrm{HOa}$ that states that "there is no statistically significant difference between the profitability ratio of the pre- and post-merger of AHLI bank". These findings relate to the studies by AlHroot (2016, 2017), Ahmed and Ahmed (2014), Liargovas and Repousis (2011), Gupta and Banerjee (2017), Sheikh et al. (2015, 2019) and Kemal (2011). Furthermore, the second group of ratios represents the liquidity ratios, which include the CCETA, DR and DTA ratios that significantly deteriorated after the merger. Furthermore, the ITA ratio deteriorated insignificantly, while the NCFD ratio increased insignificantly, so we accepted hypothesis $\mathrm{HOb}$ that states that "there is no statistically significant difference between the liquidity ratio of prev and post-merger of AHLI bank", these findings are associated with the studies by Gupta and Banerjee (2017), Cheng et al. (2020) and Gjirja (2003). The third group of ratios is represented by the leverage ratios, which include the ER and TDTE ratios; both ratios increased significantly, so we reject hypothesis H0c that states that "there is no statistically significant difference between the leverage ratio of pre- and post-merger of AHLI bank". Finally, the fourth group which includes the one and only CCFPAT ratio increased insignificantly, so we accepted hypothesis HOd that states "there is no statistically significant difference between the cash flow ratio of pre- and post-merger of AHLI bank".

\section{Findings and Conclusion}

This paper aims to examine the impact of mergers on the financial performance of the Jordanian banking sector. This paper applies the financial approaches in analyzing 
Table 5: Mann-Whitney $U$ test; mean ranks and sum of ranks

\begin{tabular}{|c|c|c|c|c|c|}
\hline Types of Financial Ratios & Ranks & status & $\mathbf{N}$ & Mean Rank & $\begin{array}{l}\text { Sum of } \\
\text { Ranks }\end{array}$ \\
\hline \multirow{12}{*}{ Profitability ratios } & \multirow{3}{*}{ ROA } & post-merger & 4 & 6.5 & 26 \\
\hline & & pre-merger & 4 & 2.5 & 10 \\
\hline & & Total & 8 & & \\
\hline & \multirow{3}{*}{ ROE } & post-merger & 4 & 6.25 & 25 \\
\hline & & pre-merger & 4 & 2.75 & 11 \\
\hline & & Total & 8 & & \\
\hline & \multirow{3}{*}{ IS } & post-merger & 4 & 5.25 & 21 \\
\hline & & pre-merger & 4 & 3.75 & 15 \\
\hline & & Total & 8 & & \\
\hline & \multirow{3}{*}{$\mathrm{IM}$} & post-merger & 4 & 6.5 & 26 \\
\hline & & pre-merger & 4 & 2.5 & 10 \\
\hline & & Total & 8 & & \\
\hline \multirow{15}{*}{ Liquidity ratios } & \multirow{3}{*}{ CCETA } & post-merger & 4 & 3 & 12 \\
\hline & & pre-merger & 4 & 6 & 24 \\
\hline & & Total & 8 & & \\
\hline & \multirow{3}{*}{ ITA } & post-merger & 4 & 3.38 & 13.5 \\
\hline & & pre-merger & 4 & 5.63 & 22.5 \\
\hline & & Total & 8 & & \\
\hline & \multirow{3}{*}{ DTA } & post-merger & 4 & 2.5 & 10 \\
\hline & & pre-merger & 4 & 6.5 & 26 \\
\hline & & Total & 8 & & \\
\hline & \multirow{3}{*}{ DR } & post-merger & 4 & 2.5 & 10 \\
\hline & & pre-merger & 4 & 6.5 & 26 \\
\hline & & Total & 8 & & \\
\hline & \multirow{3}{*}{ NCFTD } & post-merger & 4 & 6 & 24 \\
\hline & & pre-merger & 4 & 3 & 12 \\
\hline & & Total & 8 & & \\
\hline \multirow{6}{*}{ Leverage ratios } & \multirow{3}{*}{ ER } & post-merger & 4 & 6.5 & 26 \\
\hline & & pre-merger & 4 & 2.5 & 10 \\
\hline & & Total & 8 & & \\
\hline & \multirow{3}{*}{ TDTE } & post-merger & 4 & 6.5 & 10 \\
\hline & & pre-merger & 4 & 2.5 & 26 \\
\hline & & Total & 8 & & \\
\hline \multirow{3}{*}{ Cash flow ratio } & \multirow{3}{*}{ CCFPAT } & post-merger & 4 & 4.75 & 19 \\
\hline & & pre-merger & 4 & 4.25 & 17 \\
\hline & & Total & 8 & & \\
\hline
\end{tabular}


Table 6: Test Statistics

\begin{tabular}{|l|c|c|c|}
\hline \multicolumn{1}{|c|}{ Ranks } & Mann-Whitney U & Wilcoxon W & Asymp. Sig. (2-tailed) \\
\hline ROA & 0 & 10 & 0.019 \\
\hline RE & 1 & 11 & 0.043 \\
\hline IS & 5 & 15 & 0.386 \\
\hline IM & 0 & 10 & 0.021 \\
\hline CCETA & 2 & 12 & 0.083 \\
\hline ITA & 3.5 & 13.5 & 0.191 \\
\hline DTA & 0 & 10 & 0.021 \\
\hline DR & 0 & 10 & 0.02 \\
\hline NCFTD & 2 & 12 & 0.083 \\
\hline ER & 0 & 10 & 0.021 \\
\hline TDTE & 0 & 10 & 0.021 \\
\hline CCFPAT & 7 & 17 & 0.773 \\
\hline
\end{tabular}

${ }^{*}$ A significance level of 0.05

the effects of mergers in Jordanian banks' performance for the two periods: four years pre-merger and four years postmerger for the period from 2001 to 2009.

The sample of the study only contains the case of the merger of the Jordan Ahli Bank (AHLI bank) with Philadelphia Bank in 2005. Financial ratios and statistical techniques in the form of a Mann-Whitney U test are used in order to assess the significance differences in the financial performance of the selected bank pre and postmerger by investigating the performance-related financial ratio groups that are expressed by leverage, liquidity, efficiency and cash flow ratio. The results show that the profitability ratios, namely the ROA, ROE, and IM ratios increased significantly, while the IS ratio increased insignificantly.

In addition, the liquidity ratios, which include the CCETA, DR and DTA ratios, significantly deteriorated after the merger. Furthermore, the ITA ratio deteriorated, while the NCFD ratio insignificantly increased. Moreover, the leverage ratios, which include the ER and TDTE significantly increased. Finally, the cash flow ratios, which include the one and only CNOA ratio increased insignificantly. Overall, we can conclude that there is an insignificant improvement in the ratios of AHLI bank in the period after the merger except for the leverage ratios, which significantly improved. The reason for the insignificant improvement in the ratios can be the same finding by Jayaraman et al. (2014) indicating that the post-merger period corresponds to the period of the global financial crisis that began in 2007. The main limitation is that we were not able to separate the impact of the global crisis as an extraneous factor from the impact of merger. On the basis of this study, we encourage new research in Jordan to assess the service, industrial, and insurance sectors, and to compare these sectors with each other to conclude which sector provide more advantages or disadvantages for other companies going through a merger or planning for it. We suggested that the number of financial ratios must be raised. Also, researchers may examine the role of management expertise in making the M\&A successful or otherwise.

\section{References}

Ahmed, M., \& Ahmed, Z. (2014). Merger and Acquisitions: Effect on Financial Performance of Banking Institutions of Pakistan. Journal of Basic and Applied Scientific Research, 4(4), 249-259.

Al-Fayoumi, N. A., \& Abuzayed, B. M. (2009). Assessment of the Jordanian banking sector within the context of GATS agreement. Banks and Bank Systems, 4(2), 69-79.

Al-Hroot, Y.A., AL-Qudah, L.A.M. \& Alkharabsha, F.I.A., (2017). The Effect of the Global Financial Crisis on the 
Level of Accounting Conservatism in Commercial Banks: Evidence from Jordan. International Journal of Business and Management, 12(2), 151-159. http://dx.doi.org/10.5539/ijbm. v12n2p151.

Al-Hroot, Y. A. (2016). The impact of mergers on financial performance of the Jordanian industrial sector. International Journal of Management \& Business Studies, 6(1), 2230-9519.

Berger, A. N. (1998). The efficiency effects of bank mergers and acquisition: A preliminary look at the 1990s data. In Bank Mergers \& Acquisitions (pp. 79-111). Boston, MA: Springer. http://dx.doi.org/10.1007/978-1-4757-2799-9_5.

Cheng, T. Y., Li, Y.-Q., Lin, Y.-E., \& Chih, H.-H. (2020). Does the Fit of Managerial Ability with Firm Strategy Matters on Firm Performance. Journal of Asian Finance, Economics and Business, 7(4), 9-19. http://dx.doi.org/10.13106/jafeb.2020. vol7.no4.9.

Ghosh, A., \& Jain, P.C., (2000). Financial leverage changes associated with corporate mergers. Journal of Corporate Finance, 6(4), 377-402. http://dx.doi.org/10.1016/s09291199(00)00007-9.

Gjirja, M. (2003). Assessing the efficiency effects of bank mergers in Sweden: A panel-based Stochastic Frontier Analysis. Goteborg, Sweden: Doctoral Dissertation, Department of Economics, Goteborg University.

Gupta, B., \& Banerjee, P. (2017). Impact of merger and acquisitions on financial performance: Evidence from selected companies in India. International Journal of Commerce and Management Research, 14-19. [Online Journal] http://www.managejournal.com/up/ conference/20170210153824.pdf

Healy, P. M., Palepu, K. G., \& Ruback, R. S. (1992). Does corporate performance improve after mergers? Journal of Financial Economics, 31(2), 135-175.

Ismail, T. H., Abdou, A. A., \& Annis, R. M. (2011). Review of literature linking corporate performance to mergers and acquisitions. The Review of Financial and Accounting Studies, 1(1), 89-104.

Jayaraman, A. R., Srinivasan, M. R., \& Arunachalam, R. (2014). Impact of merger and acquisition on the efficiency of Indian banks: a pre-post analysis using data envelopment analysis. International Journal of Financial Services Management, 7(1), 1-18.

Kemal, M. U. (2011). Post-merger profitability: A case of Royal Bank of Scotland (RBS). International Journal of Business and Social Science, 2(5), 157-162.]
Kumar, R. (2009). Post-merger corporate performance: an Indian perspective. Management Research News, , 32(2), 145-157. https://doi.org/10.1108/01409170910927604

Kumbirai, M., \& Webb, R. (2010). A financial ratio analysis of commercial bank performance in South Africa. African Review of Economics and Finance, 2(1), 30-53.

Leepsa, N. M., \& Mishra, C. S. (2012). Post merger financial performance: a study with reference to select manufacturing companies in India. International Research Journal of Finance and Economics, 83(83), 6-17.

Liargovas, P., \& Repousis, S., (2011). The Impact of Mergers and Acquisitions on the Performance of the Greek Banking Sector: An Event Study Approach. International Journal of Economics and Finance, 3(2), 89-100. http://dx.doi.org/10.5539/ijef.v3n2p89.

Reddy, K.S., Nangia, V.K., \& Agrawal, R., (2014). The 20072008 Global Financial Crisis, and Cross-border Mergers and Acquisitions. Global Journal of Emerging Market Economies, 6(3), 257-281. http://dx.doi.org/10.1177/0974910114540720.

Said, R. M., Nor, F. M., Low, S. W., \& Rahman, A. A. (2008). The efficiency effects of mergers and acquisitions in Malaysian banking institutions. Asian Journal of Business Accounting, 1(1), 47-66.

Shah, B. A., \& Khan, N. (2017). Impacts of mergers and acquisitions on acquirer banks' performance. Australasian Accounting, Business and Finance Journal, 11(3), 30-54.

Sheikh, M. F., Bhutta, A. I., \& Sultan, J. (2019). CEO Compensation and Unobserved Firm Performance in Pakistan. Journal of Asian Finance, Economics and Business, 6(3), 305-313. http:// dx.doi.org/10.13106/jafeb.2019.vol6.no3.305.

Sheikh, M. J., Ahmed, M., Arshad, Q., \& Shakeel, W. (2015). Mergers and Acquisitions as Vital Instruments of Corporate Strategy: Current and Historical Perspective. Journal of Asian Finance, Economics and Business, 2(1), 15-21. http://dx.doi. org/10.13106/jafeb.2015.vol2.no1.15.

Sufian, F., \& Majid, M. Z. A. (2007). The performance of mergers and acquisitions in the Singapore banking sector: An application of two-stage banking models. Labuan Bulletin of International Business and Finance, 5, 67-96.

Sulaiman, L. A. (2012). Does restructuring improve performance? An industry analysis of Nigerian oil \& gas sector. Research Journal of Finance and Accounting, 3(6), 55-62.

Vitale, R. \& Laux, J.A., (2012). The Economic Efficacy of Banking Mergers: 2006-2008. Journal of Applied Business Research, 28(6), 1211-1216. http://dx.doi.org/10.19030/jabr.v28i6.7336. 


\section{Annexes}

Annex-A: Banks in Jordan

\begin{tabular}{|c|c|c|c|}
\hline Bank Name & Ticker & Origin & Type \\
\hline Al Rajhi Bank & Not listed & Foreign & Islamic \\
\hline Arab Bank & ARBK & Local & Commercial \\
\hline Arab Banking Corporation & $\mathrm{ABCO}$ & Local & Commercial \\
\hline Arab Jordan Investment Bank & AJIB & Local & Commercial \\
\hline Bank Al Etihad & UBSI & Local & Commercial \\
\hline Bank of Jordan & BOJX & Local & Commercial \\
\hline Banque Audi & Not listed & Foreign & Commercial \\
\hline Blom Bank & Not listed & Foreign & Commercial \\
\hline Cairo Amman Bank & CABK & Local & Commercial \\
\hline Capital Bank of Jordan & EXFB & Local & Commercial \\
\hline Citi Bank & Not listed & Foreign & Commercial \\
\hline Egyptian Arab Land Bank & Not listed & Foreign & Commercial \\
\hline Invest bank & INVB & Local & Commercial \\
\hline Islamic International Arab Bank & Not listed & Local & Islamic \\
\hline Jordan Ahli Bank & AHLI & Local & Commercia \\
\hline Jordan Commercial Bank & JCBK & Local & Commercial \\
\hline Jordan Dubai Islamic Bank & JDIB & Local & Islamic \\
\hline Jordan Islamic Bank & JOIB & Local & Islamic \\
\hline Jordan Kuwait Bank & JOKB & Local & Commercial \\
\hline National Bank of Abu Dhabi & Not listed & Foreign & Commercial \\
\hline National Bank of Kuwait & Not listed & Foreign & Commercial \\
\hline Rafidain Bank & Not listed & Foreign & Commercial \\
\hline Societe Generale de Banque Jordanie & SGBJ & Local & Commercial \\
\hline Standard Chartered & Not listed & Foreign & Commercial \\
\hline The Housing Bank for Trade and Finance & THBK & Local & Commercial \\
\hline
\end{tabular}

Source: Central Bank of Jordan www.cbj.gov.jo

Annex-B: Merged companies distributed by related sectors

\begin{tabular}{|l|c|c|}
\hline \multicolumn{1}{|c|}{ Sector } & Number of Merged companies & Merged company's percentage \\
\hline Industrial & 10 & $\mathbf{4 1 . 6 7 \%}$ \\
\hline Financial and Banks & 2 & $\mathbf{8 \%}$ \\
\hline Insurance & - & $\mathbf{0} \%$ \\
\hline Services & 12 & $\mathbf{5 0 \%}$ \\
\hline Total & $\mathbf{2 4}$ & $\% 100$ \\
\hline
\end{tabular}

